I N F ORM A T I R

Jurnal Informatika, Manajemen dan Komputer, Vol. 10 No. 2, Desember 2018

eISSN : 2580-3042

pISSN : 1979-0694

\title{
SISTEM INFORMASI PEMBAYARAN SPP DI SMK NEGERI 4 DUMAI BERBASIS SMS GATEWAY
}

\author{
Suci Anggraini ${ }^{1}$, Amat Sofiyan ${ }^{2}$, Hayatullah Khumaini ${ }^{3}$ \\ ${ }^{1,2,3}$ Sekolah Tinggi Managemen Informatika dan Komputer (STMIK) Dumai \\ 1,2,3 Jl.Utama Karya Bukit Batrem II Dumai-Riau kode pos 28811 \\ e-mail: sanggraini784@gmail.com
}

\begin{abstract}
ABSTRAK
SPP atau Sumbangan Pembinaan Pendidikan adalah sejumlah biaya yang dibebankan kepada siswa untuk membantu lembaga pendidikan memperlancar proses belajar mengajar. SPP merupakan iuran rutin sekolah yang mana pembayarannya dilakukan setiap sebulan sekali.SPP merupakan salah satu bentuk kewajiban setiap siswa yang masih aktif dilembaga tersebut. Pengelolaan informasi data pembayaran SPP Di SMK Negeri 4 Dumai saat ini masih konvensional dengan mencatat pada kartu pembayaran kemudian data pembayaran direkap pada buku. Selain itu masih kurangnya informasi dari pihak sekolah kepada orang tua atau wali siswa mengenai transaksi pembayaran dan informasi penunggakan pembayaran SPP siswa. Untuk membuat sebuah sistem yang dapat membantu proses pengolahan data administrasi pembayaran SPP di SMK Negeri 4 Dumai. Sistem informasi pembayaran SPP dibuat dengan menggunakan bahasa pemrograman PHP (Hypertext Preprocessor) serta menggunakan database MySQL dan menggunakan metode SDLC.
\end{abstract}

Kata kunci : SPP, Pembayaran, Penunggakan,PHP,Mysql

\section{PENDAHULUAN}

Sekolah Menengah Kejuruan (SMK) Negeri 4 Dumai merupakan salah satu lembaga pendidikan formal yang berkembang di kota Dumai. SMK Negeri 4 Dumai terletak di Jalan Pesantren Kelurahan Tanjung Penyembal Kecamatan Sungai Sembilan Kota Dumai yang berdiri di atas lahan seluas $2 \mathrm{Ha}$.

Dilihat dari aktivitas yang ada pada bagian bendahara komite SMK Negeri 4 Dumai, dalam pengelolaan informasi data pembayaran SPP siswa saat ini masih dilakukan secara konvensional dengan mencatat pada kartu pembayaran kemudian data pembayaran direkap pada buku. ini membutuhkan waktu yang lama dan berdampak pada lamanya penyajian informasi yang dibutuhkan, kendala lainnya adalah masih sering terjadinya kesalahan perhitungan, salah dalam memasukkan data, dan juga laporan keuangan yang disajikan kurang memadai. Dan apabila dibutuhkan suatu data, bendahara harus mengurutkan satu persatu dari seluruh data yang ada sampai data yang diinginkan ditemukan. Kendala lainnya juga yang menjadi masalah utama adalah kurangnya informasi dari pihak sekolah kepada orang tua atau wali siswa mengenai transaksi pembayaran SPP dan informasi keterlambatan pembayaran sehingga banyaknya keterlambatan pembayaran oleh siswa dan siswi yang akan berdampak besar pada kelancaran jalannya proses kegiatan belajar mengajar, dan ketika orang tua atau wali siswa membayar uang SPP, mereka menitipkannya kepada anak/siswa yang bersangkutan, sehingga terindikasi adanya penyalahgunaan uang pembayaran SPP oleh siswa.

Sehingga Dengan Adanya Sistem Informasi Pembayaran SPP ini, Dapat Mempermudah Bagi Bendahara Dalam Pengolahan Dan Manajemen Data Pembayaran SPP Siswa, Juga Mempermudah Bagi Orang Tua Atau Wali Siswa Dalam Mengetahui Informasi Pembayaran Dan Penunggakan SPP Siswa, Serta Siswa Tidak Dapat Menyalahgunaan Uang Pembayaran SPP Ketika Orang Tua Atau Wali Siswa Menitipkan Uang Pembayaran Spp Kepada Anak/Siswa Yang Bersangkutan.

a. PHP

PHP singkatan dari PHP: Hypertext Preprocessor yang digunakan sebagai bahasa script server-side dalam pengembangan web yang disisipkan dalam dokumen HTML Penggunaan PHP memungkinkan web dapat 


\section{INFORM T I K}

Jurnal Informatika, Manajemen dan Komputer, Vol. 10 No. 2, Desember 2018

eISSN : 2580-3042

pISSN : 1979-0694

dinamis sehingga maintenance situs web tersebut menjadi lebih mudah dan efisien. PHP merupakan software Open-source yang disebarkan dan dilisensikan secara gratis serta dapat di download secara bebas dari situs resminya http://www.php.net. (Fristanto, 2013)

\section{b. Database (Basis Data)}

Database adalah kumpulan data yang saling berhubungan (relasi). Istilah tersebut bisa digunakan pada sistem-sistem yang terkomputerisasi. Dalam pengertian umum, database diartikan sebagai gabungan dari elemen eleman data yang berhubungan dengan teroganisir.(Yuhendra \& Eko Yulianto, 2015)

\section{c. MySQL}

MySQL adalah database server relational yang gratis dibawah lisensi GNU General Public Licence. Dengan sifatnya yang open source, memungkinkan juga user untuk melakukan modifikasi pada souce code-nya untuk memenuhi kebutuhan spesifik mereka sendiri. MySQL merupakan database server multi-user dan multi- threaded yang tangguh (rebust). Dengan memiliki banyak feature MySQL bisa bersaing dengan database komersial sekalipun. MySQL menjadi database pilihan untuk banyak pengguna PHP. (Nurfajrina, Suryatiningsih;, \& Siswanto, 2016)

\section{d. Gammu}

Gammu adalah service yang disediakan untuk membangun aplikasi yang berbasis SMS gateway. Selain mudah, aplikasi SMS gateway dengan gammu adalah free. Ada dua mekanisme kerja dari gammu yaitu sebagai aplikasi dan sebagai deamon. Gammu sebagai aplikasi akan bekerja ketika perintah gammu dijalankan pada lingkungan shell beserta perintahnya disertakan sesuai fungsi yang diinginkan. Sedangkan sebagai deamon, gammu ditandai dengan dijalankannya perintah smsd pada shell. Pada prinsipnya cara kerja gammu yaitu menghubungkan modem/ponsel dengan PC. SMS yang diterima di modem / ponsel akan diambil oleh gammu untuk dipindahkan ke dalam database yang telah diatur sebelumnya. (Afrina \& Ibrahim, 2015)

\section{e. Bootstrap}

Bootstrap merupakan sebuah framework yang dapat menyelesaikan permasalahan dalam mendesain web. Slogan dari framework ini adalah "Sleek, intuitive, and powerful front-end

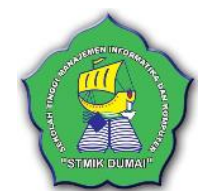

framework for faster and easier web development", yang berarti kita dapat mendesain sebuah website dengan lebih rapi, cepat dan mudah. Selain itu Bootstrap juga responsive terhadap banyak platform, artinya tampilan halaman website yang menggunakan Bootstrap ini akan tampak tetap rapi, baik versi mobile maupun desktop.(Zakir, 2016)

\section{f. Aliran Sistem Informasi}

Merupakan bagan alir yang menunjukkan arus dari laporan dan formulir termasuk tembusan-tembusannya. Untuk itu dibutuhkan pedoman- pedoman untuk membuat Aliran Sistem Informasi (ASI). (Iswandy, 2015)

\section{g. Contex Diagram}

Context diagram merupakan data flow diagram yang menggambarkan garis besar operasional sistem. Konteks diagram menggambarkan hubungan sistem dengan entitas-entitas di luar sistem. CD memperlihatkan sistem sebuah proses. Tujuannya adalah memberikan pandangan umum sistem. CD memperlihatkan sebuah proses yang berinteraksi dengan lingkungan luarnya. Ada pihak luar yang memberikan masukan dan pihak yang menerima keluaran sistem.(Iswandy, 2015)

\section{h. Data Flow Diagram}

Diagram aliran data sistem disebut juga dengan Data Flow Diagram (DFD). DFD sering digunakan untuk menggambarkan suatu sistem yang telah ada atau sistem baru yang akan dikembangkan secara logika tanpa mempertimbangkan lingkungan fisik dimana data tersebut mengalir atau lingkungan fisik dimana data tersebut disimpan. DFD menggambarkan arus data didalam sistem dengan terstruktur dan jelas. (Iswandy, 2015)

\section{i. Entity Raltionship Diagram}

Entity Relationship Diagram (ERD) memiliki dua komponen utama yaitu Entitas (Entity) dan Relasi (Relation). Kedua komponen ini ,masing-masing dilengkapi dengan sejumlah atribut yang mempresentasikan seluruh fakta yang ada di dunia nyata. (Iswandy, 2015)

\section{j. Flowchart}

Flowchart merupakan urutan-urutan langkah kerja suatu proses yang digambarkan dengan menggunakan simbol-simbol yang disusun secara sistematis. Simbol-simbol. (Iswandy, 2015) 
I N F O R M A I I A

Jurnal Informatika, Manajemen dan Komputer, Vol. 10 No. 2, Desember 2018

eISSN : 2580-3042

pISSN : 1979-0694

\section{METODELOGI PENELITIAN}

Untuk membantu dalam penyusunan metode penelitian ini, maka perlu adanya susunan kerangka kerja yang jelas tahapantahapannya. Kerangka kerja ini merupakan langkah-langkah yang akan dilakukan dalam penyelesaian masalah yang ada di SMK Negeri 4 Dumai, berikut adalah kerangka kerja:

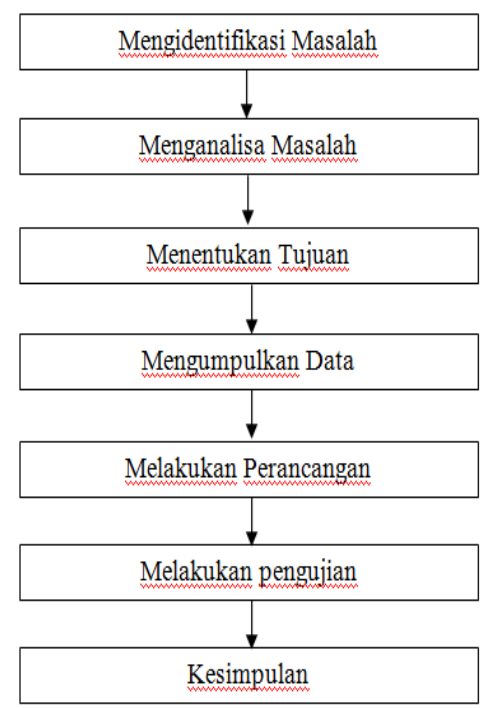

Gambar 1. Kerangka Kerja

Berdasarkan gambar,dapat dijabarkan urutan-urutan langkah kerja sebagai berikut:

1. Mengidentifikasi Masalah

Permasalahan utama dalam penelitian ini ialah kurangnya penyediaan informasi kepada orang tua atau wali siswa mengenai transaksi pembayaran SPP dan informasi keterlambatan pembayaran SPP siswa.

2. Menganalisa masalah

Penganalisaan terhadap masalah yang telah diindentifikasi perlu dilakukan, apakah data mengenai pembayaran SPP di SMK Negeri 4 Dumai dapat dianalisa dan ditambah dengan sistem informasi pembayaran SPP dengan bantuan SMS Gateway. Dengan tujuan untuk mempermudah penyampaian informasi kepada wali siswa perihal pembayaran atau penunggakan pembayaran SPP siswa.

3. Menentukan Tujuan

Tujuan utama dalam penelitian ini adalah untuk menyediakan informasi kepada orang tua atau wali siswa mengenai transaksi pembayaran SPP dan informasi keterlambatan pembayaran dengan laporan berbasis SMS Gateway.

4. Mengumpulkan data

Pengumpulan data mengenai data pembayaran SPP diperoleh dengan cara

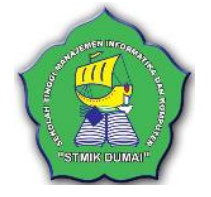

melakukan pengamatan langsung ke SMK Negeri 4 Dumai.

5. Melakukan Perancangan

Adapun penjelasan lebih rinci mengenai perancangan sistem informasi pembayaran SPP pada SMK Negeri 4 Dumai digambarkan dengan menggunakan DFD.

6. Melakukan Pengujian

Melakukan pengujian merupakan proses terakhir sebelum mendapatkan pengetahuan baru dari data yang ada. Pada tahap ini, hasil penerapan SMS Gateway menggunakan software Gammu 1.32 akan dilakukan pengujian kembali, dengan tujuan untuk mendapatkan hasil yang maksimal dari data yang ada.

7. Kesimpulan

Setelah dilakukan pengujian, langkah berikutnya adalah penentuan atau pengambilan keputusan berdasarkan hasil yang telah dilakukan sebelumnya, sehingga akan muncul hasil program yang prioritas atau yang tidak prioritas.

\section{HASIL DAN PEMBAHASAN}

a. Aliran Sistem Informasi Yang Sedang Berjalan (ASI Lama)

Aliran Sistem Informasi yang sedang berjalan (ASI lama) pada sistem pembayaran SPP di SMK Negeri 4 Dumai dapat dilihat pada gambar 2 dibawah ini:

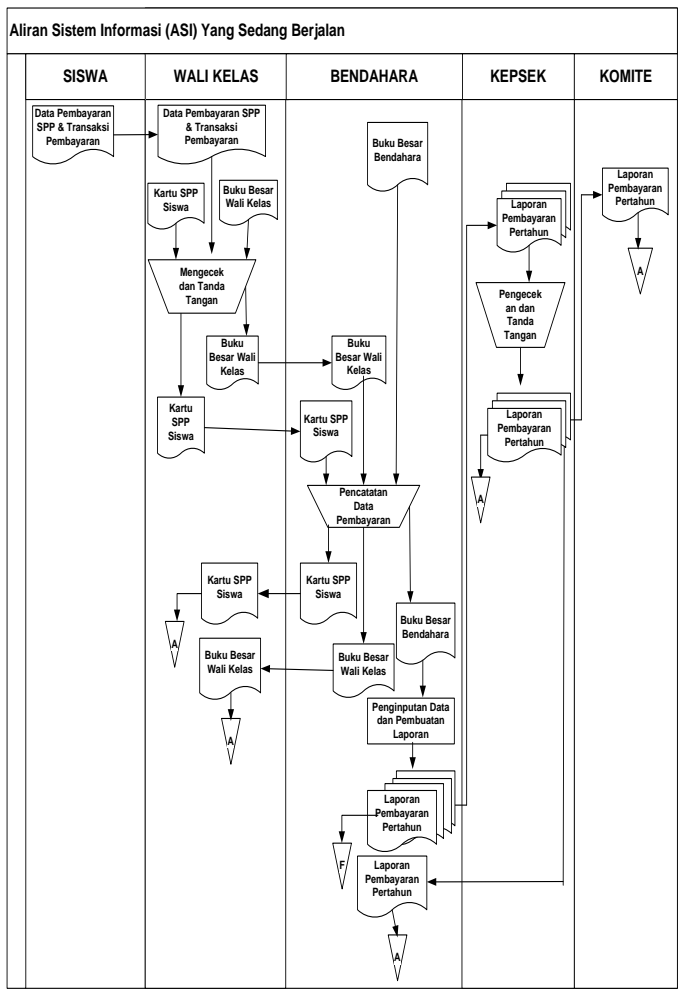

Gambar 2. ASI Lama 
IN F ORM A T IK A

Jurnal Informatika, Manajemen dan Komputer, Vol. 10 No. 2, Desember 2018

eISSN : 2580-3042

pISSN : 1979-0694

Berikut adalah keterangan dari gambar 2 aliran sistem informasi yang sedang berjalan pada sistem pembayaran SPP di SMK Negeri 4 Dumai yaitu:

1. Siswa menyerahkan data pembayaran SPP dan melakukan transaksi pembayaran ke wali kelas.

2. Wali kelas menyimpan data pembayaran SPP siswa, kartu SPP siswa, dan buku besar wali kelas. Kemudian Wali kelas mengecek kartu SPP dan mengecek buku besar wali kelas serta melakukan pengecekan dan tanda tangan.

3. Setelah dicek dan di tanda tangan, wali kelas menyerahkan buku besar wali kelas dan kartu SPP siswa ke bendahara.

4. Bendahara menyimpan buku besar bendahara.

5. Bendahara mencatat dan menandatangani buku besar bendahara, buku besar wali kelas, beserta kartu SPP siswa. Kemudian memasukkan ke microsoft office excel.

6. Bendahara mencetak laporan pembayaran SPP Pertahun sebanyak 4 rangkap, 1 rangkap di arsip berbentuk file, 3 rangkap diserahkan kepada kepala sekolah untuk di cek dan ditanda tangani.

7. Laporan yang sudah ditandatangani oleh kepala sekolah, 1 rangkap diserahkan ke bendahara untuk diarsip, 1 rangkap untuk komite untuk diarsip.

\section{b. Aliran Sistem Informasi Yang Baru (ASI Baru)}

Berikut keterangan dari gambar 3 aliran sistem informasi yang baru pada sistem pembayaran SPP di SMK Negeri 4 Dumai.

1. Siswa menyerahkan data pembayaran SPP dan melakukan transaksi pembayaran ke wali kelas.

2. Wali kelas menyimpan data pembayaran SPP siswa, kartu SPP siswa, dan buku besar wali kelas. Kemudian Wali kelas mengecek kartu SPP dan mengecek buku besar wali kelas serta melakukan pengecekan dan tanda tangan.

3. Setelah dicek dan di tanda tangan, wali kelas menyerahkan buku besar wali kelas dan kartu SPP siswa ke bendahara.

4. Bendahara menyimpan buku besar bendahara.

5. Bendahara mencatat dan menandatangani buku besar wali kelas, buku besar bendahara, beserta kartu SPP siswa dan memasukkan data nya ke sistem.

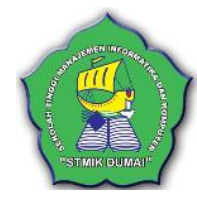

6. Kemudian bendahara menyerahkan kembali buku besar wali kelas dan kartu pembayaran SPP siswa ke wali kelas.

7. Kepala sekolah dan komite mengakses informasi data pembayaran SPP siswa disistem.

8. Bendahara menginput data pembayaran SPP siswa, membuat laporan serta mencetak laporan pembayaran SPP perstahun sebanyak 4 rangkap, 1 rangkap di arsip berbentuk file, 3 rangkap diserahkan kepada kepala sekolah untuk di cek dan ditanda tangani.

9. Laporan yang sudah ditandatangani oleh kepala sekolah, 1 rangkap diserahkan ke bendahara untuk diarsip, 1 rangkap untuk komite untuk diarsip.

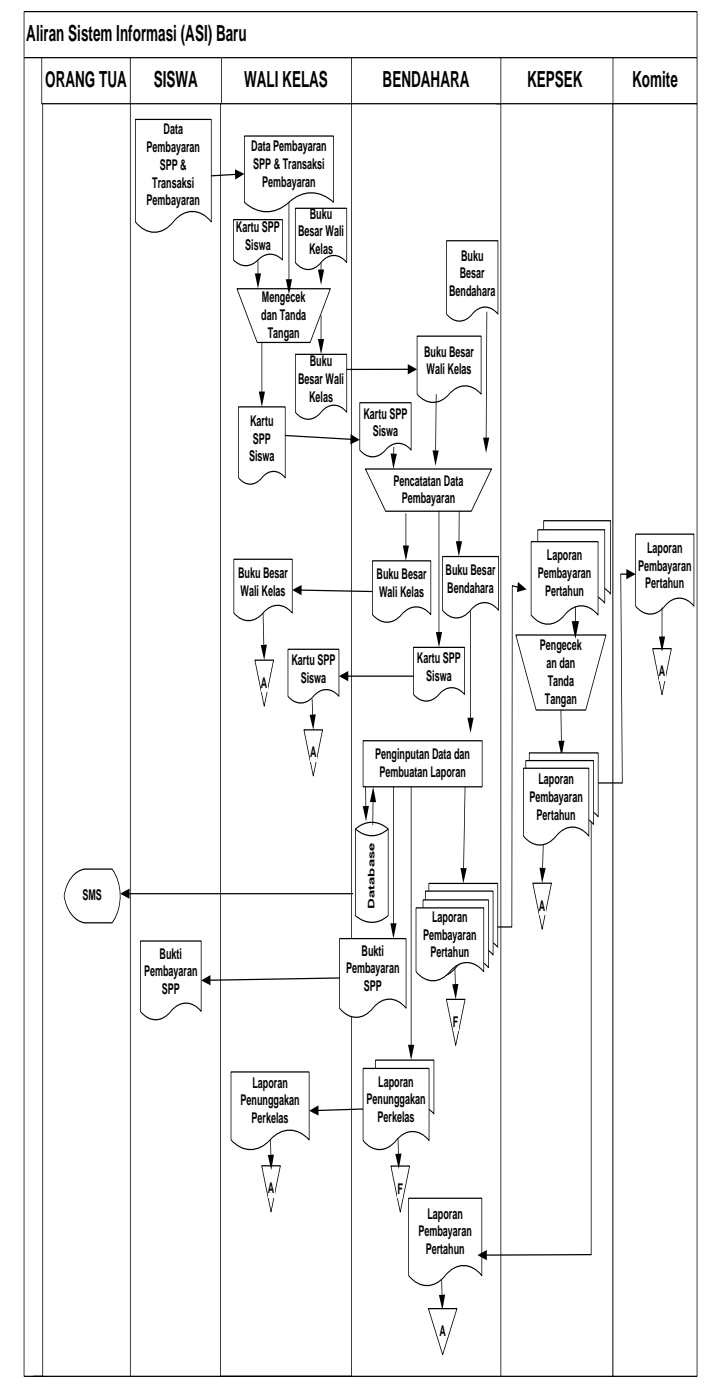

Gambar 3 ASI Baru 
I N F ORM A T I R

Jurnal Informatika, Manajemen dan Komputer, Vol. 10 No. 2, Desember 2018

eISSN : 2580-3042

pISSN : 1979-0694

\section{c. Contex Diagram}

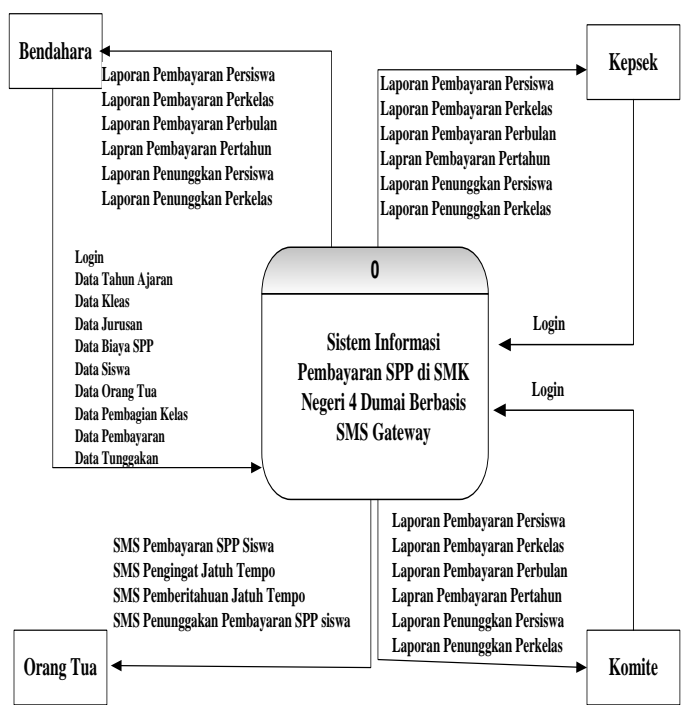

Gambar 4. Contex Diagram

\section{d. Data Flow Diagram}

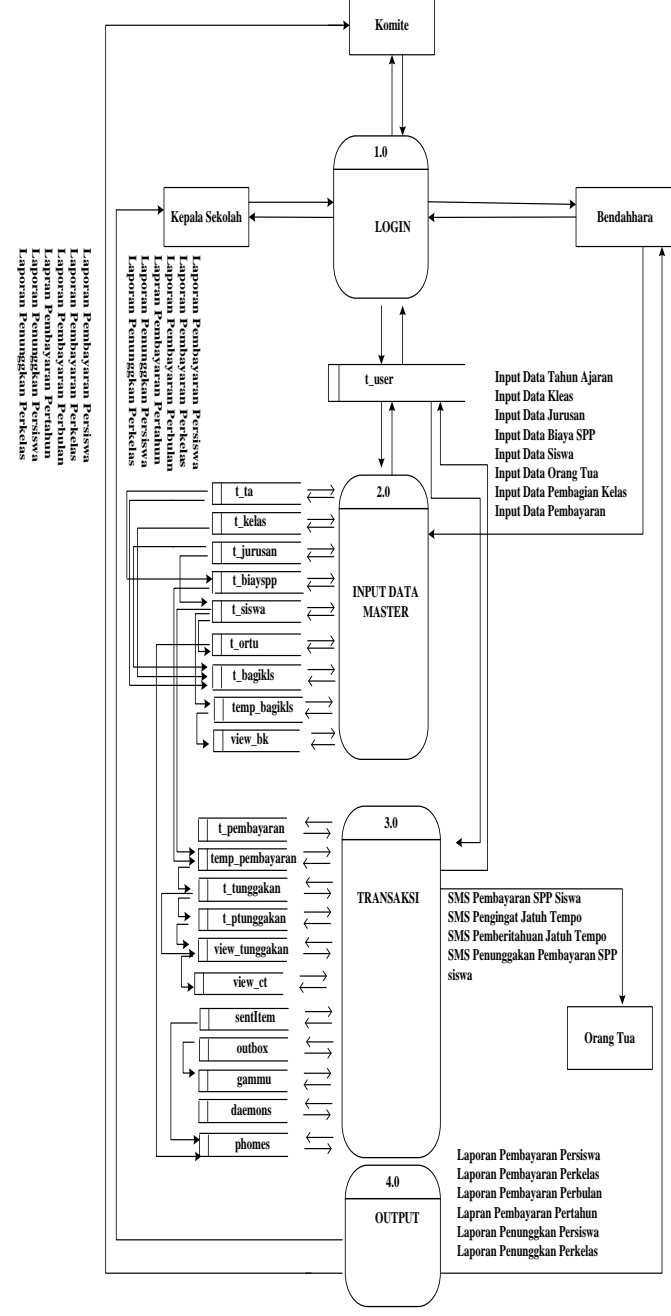

e. Tampilan Program

1. Menu Utama Admin

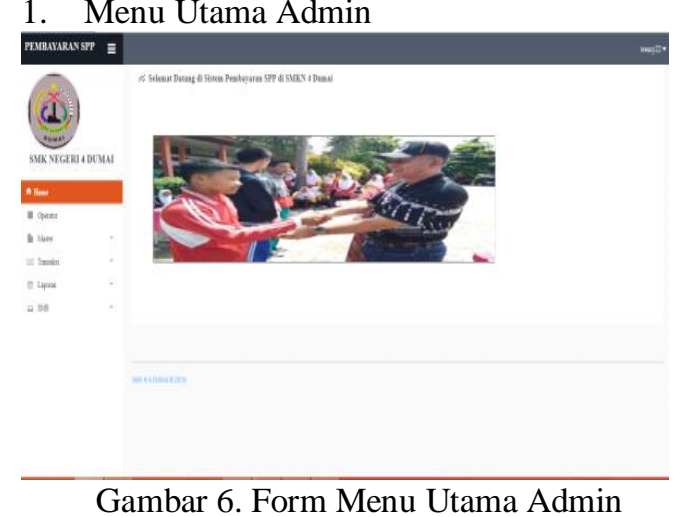

Didalam menu utama Admin terdapat menu-menu yang memiliki fungsi masingmasing, yaitu menu operator, menu master, transaksi, dan laporan. Pada menu operator berfungsi untuk menambah, mengedit, dan menghapus hak akses program. Didalam menu master terdapat sub menu data tahun ajaran, data kelas, data jurusan, data biaya spp, data siswa, dan data pembagian kelas. Di dalam menu transaksi terdapat sub menu pembayaran spp dan penunggakan spp siswa. Sedangkan dilaporan terdapat laporan data pembayaran persiswa, perkelas, perbulan, dan pertahun serta laporan penunggakan persiswa dan perkelas.

\section{Data Pmbayaran}

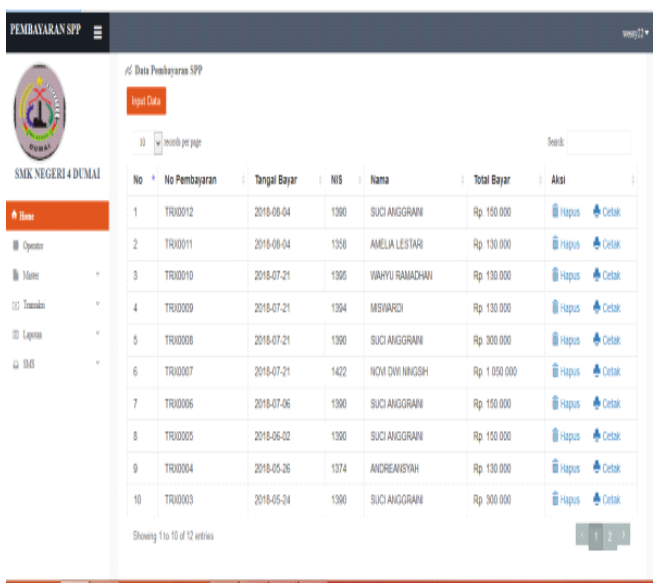

Gambar 7. Form Data Pembayaran

Pada form data pembayaran terdapat penginputan data/ tambah data pembayaran dan aksi. Pada aksi terdapat perintah "Hapus", dan "Cetak". Printah "Hapus" untuk menghapus data. Perintah "Cetak" untuk mencetak bukti pembayaran yang dipilih.

Gambar 5. Data Flow Diagram 
I N F ORM A T I R

Jurnal Informatika, Manajemen dan Komputer, Vol. 10 No. 2, Desember 2018

eISSN : 2580-3042

pISSN : 1979-0694

3. Data Input Bayar

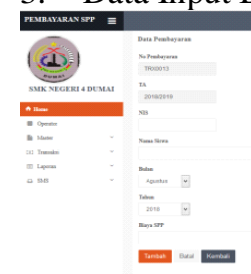

Gambar 8. Form Data Pembayaran

SPP siswa bisa dibayar lebih dari 1 bulan, Setiap data pembayaran yang ditambah otomatis sms pembayaran masuk ke nomor handphone orang tua siswa yang membayar SPP.

\section{Data Tunggakan}

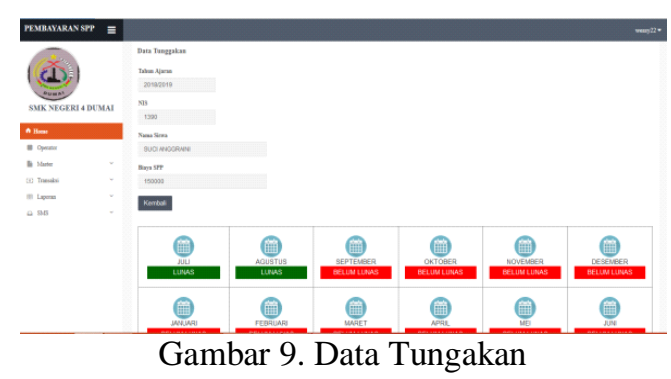

Pada data tunggakan SPP menampilkan data pembayaran bulanan yang sudah dan yang belum bayar.

5. Laporan Pembayaran Pertahun

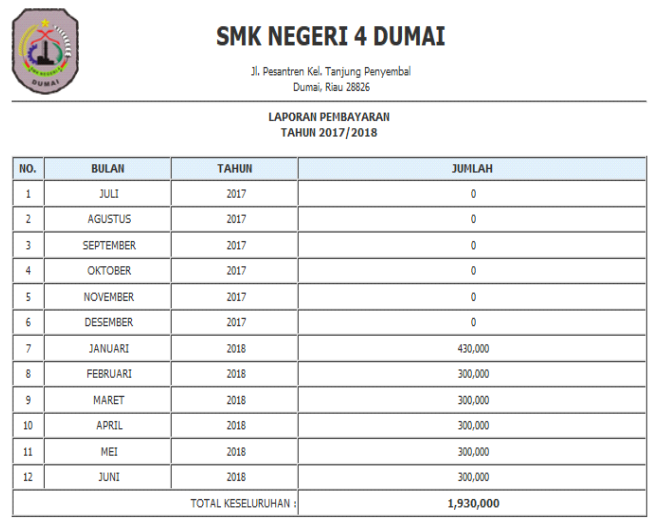

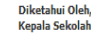

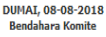

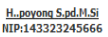

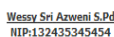

Gambar 10. Data Laporan Pertahun

Jumlah bayar pada setiap 1 bulan menghitung pembayaran yang sudah dibayar selama bulan tersebut. Contohnya pada bulan januari diatas, jumlah bayar pada bulan januari
2018 mencapai 430.000 dari setiap siswa dan setiap jurusan yang sudah dibayar. Data ini menghitung jumlah pembayaran dari setiap bulan dan mentotalkan keseluruhannya dalam 1 tahun.

6. Laporan Pembayaran Persiswa
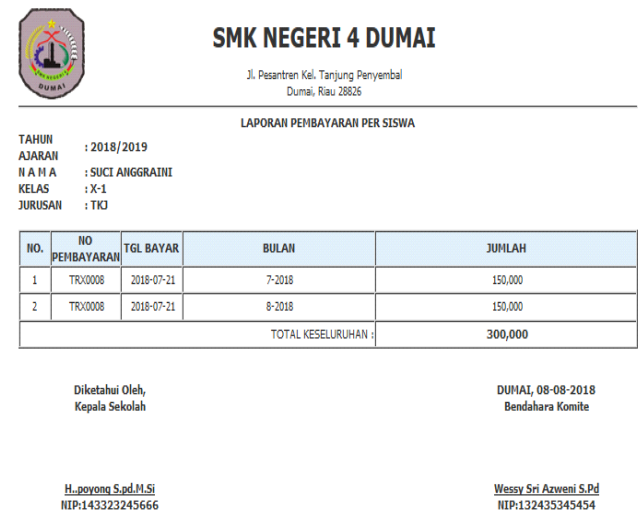

Gambar 11. Data Laporan Persiswa

7. Laporan Data Penunggakan

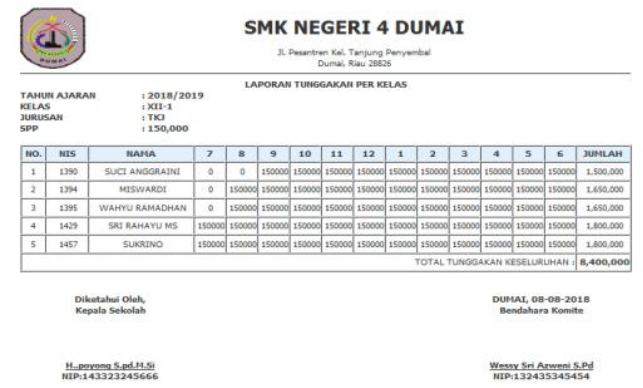

Gambar 12. Laporan Penunggakan Perkelas

Data laporan penunggakan perkelas menampilkan data siswa dalam 1 kelas yang menunggak membayar SPP. Jumlah disana menghitung jumlah pembayaran yang belum dibayar selama 1 tahun.

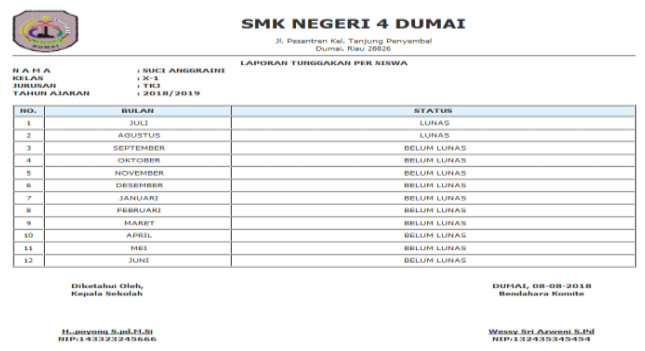

Gambar 13. Laporan Penunggakan Persiswa

Pada data laporan tunggakan SPP persiswa menampilkan data pembayaran bulanan yang sudah dan yang belum bayar. 


\section{N F O R M A I K}

Jurnal Informatika, Manajemen dan Komputer, Vol. 10 No. 2, Desember 2018

eISSN : 2580-3042

pISSN : 1979-0694

\section{KESIMPULAN}

Beberapa kesimpulan yang dapat diambil dari pembahasan dan penerapan sistem informasi pembayaran SPP di SMK N 4:

a. Dengan dibuatnya sistem ini diharapkan dapat mempermudah bendahara dalam pengolahan dan manajemen data pembayaran SPP siswa dan mempermudah orang tua/wali siswa dalam mengetahui informasi pembayaran dan penunggakan SPP siswa melalui SMS Gateway.

b. Dengan adanya pengiriman informasi mengenai tunggakan sehingga orang tua dapat lebih cepat mengetahui informasinya.

\section{REFERENSI}

Afrina, M., \& Ibrahim, A. (2015). Pengembangan Sistem Informasi Sms Gateway Dalam Meningkatkan Layanan Komunikasi Sekitar Akademika Fakultas Ilmu Komputer Unsri. Issn Print, 7(2), 2085-1588. Retrieved From Http://Ejournal.Unsri.Ac.Id/Index.Php/Jsi/ Index

Fristanto, H. T. (2013). Rancang Bangun Sistem Informasi Pembayaran Sumbangan Pembinaan Pendidikan (Spp) Dan Insidental Pada Sekolah Menengah Kejuruan Muhammadiyah Tinatar Punung Hendria Tony Fristanto 1) Bambang Eka Purnama 2) Sukadi 3). Indonesian Journal On Networking And Security, 3(4), 1-5.

Garber, T., Goldenberg, J., Libai, B., \& Muller, E. (2004). [ No Title ]. Marketing Science, 23(3), 419-428.

Ismael. (2017). Jurnal Edikinformatika Semen Padang Untuk Daerah Bengkulu Selatan Di Jurnal Edikinformatika. Jurnal Edikinformatika, 2(2), 147-156.

Iswandy, E. (2015). Sistem Penunjang Keputusan Untuk Menentukan Penerimaan Dana Santunan Sosial Anak Nagari Dan Penyalurannya Bagi Mahasiswa Dan Pelajar Kurang Mampu Di Kenagarian Barung - Barung Balantai Timur. Jurnal Teknoif, 3(2), 70-79. Https://Doi.Org/2338-2724

Kaharu, S., \& Sakina, O. (2015). Perancangan Sistem Informasi Pengolahan Data Akademik Pada Tk Al-Hidayah Lolu. Prototyping Adalah Proses Menghasilkan Sebuah Ide Atau Gagasan Bagi Pembuat Maupun Pemakai Potensial Tentang Cara

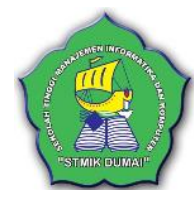

System Yang Akan Berfungsi Dalam Bentuk Lengkapnya. Ada, 8(1), 73-79. Https://Doi.Org/10.1016/J.Jmmm.2006.10 .792

Nurfajrina, D., Suryatiningsih;, \& Siswanto, B. (2016). Aplikasi Pembayaran Bulanan Berbasis Web Dan Sms Gateway Di Smk Negeri 3 Bandung. E-Proceeding of Applied Science, 2(3), 1090-1097. Retrieved From Http://Libraryeproceeding.Telkomunivers ity.Ac.Id/Index.Php/Appliedscience/Articl e/Viewfile/3471/3293

Nurlela, F. (2013). Aplikasi Sms Gateway Sebagai Sarana Penunjang Informasi Perpustakaan Pada Sekolah Menegah Pertama Negeri 1 Arjosari. Indonesian Journal On Networking And Security, 2(4), 20-25.

Https:/Doi.Org/10.1016/S09205632(95)80092-1

Rohayati, \& Hj, A. I. (2016). Perancangan Dan Implementasi Sistem Informasi Inventaris Laboratorium. Jurnal Intekna, 16(2), 1519.

Sentosa, Y., Hadiansa, A., \& Rubiati, N. (2017). Aplikasi Pembuatan Kartu Pengenal Siswa Dan Siswi Sekolah Menengah Pertama (Smp) Ykpp Dumai. Jurnal Informatika, Manajemen Dan Komputer, 9(1), 44-48. Retrieved From Http://Www.Ejournal.Stmikdumai.Ac.Id/I ndex.Php/Path/Article/View/63

Yuhendra, D. E., \& Eko Yulianto, R. (2015). Rekayasa Perangkat Lunak Pengolahan Data Distribusi Obat- Obatan Di Pt. Anugrah Pharmindo Lestari Berbasis Web. Jurnal Momentum, 17(Agustus), 8.

Yunita, P. (2018). Aplikasi Perhitungan Payroll Dosen Pada Stmik Dumai. Jurnal Informatika, Manajemen Dan Komputer, 10(1), 18-21. Retrieved From Http://Www.Ejournal.Stmikdumai.Ac.Id/I ndex.Php/Path/Article/View/56

Zakir, A. (2016). Rancang Bangun Responsive Web Layout Dengan Menggunakan Bootstrap Framework. Infotekjar (Jurnal Nasional Informatika Dan Teknologi Jaringan), 1(Issn : 2540-7600), 7-10. Https://Doi.Org/10.30743/Infotekjar.V1i1 .31 